DOI: 10.11606/issn.2238-3867.v16i1p5-38

sala preta

ppgac

Dossiê Performatividades Originárias

\title{
O Grande Teatro de Paucartambo
}

\author{
The Great Theater of Paucartambo
}

Miguel Rubio Zapata

Miguel Rubio Zapata

Diretor do principal grupo de teatro peruano, Yuyachkani. Pesquisador do teatro latino-americano que trocou experiências nos últimos 45 anos com os principais criadores teatrais do mundo

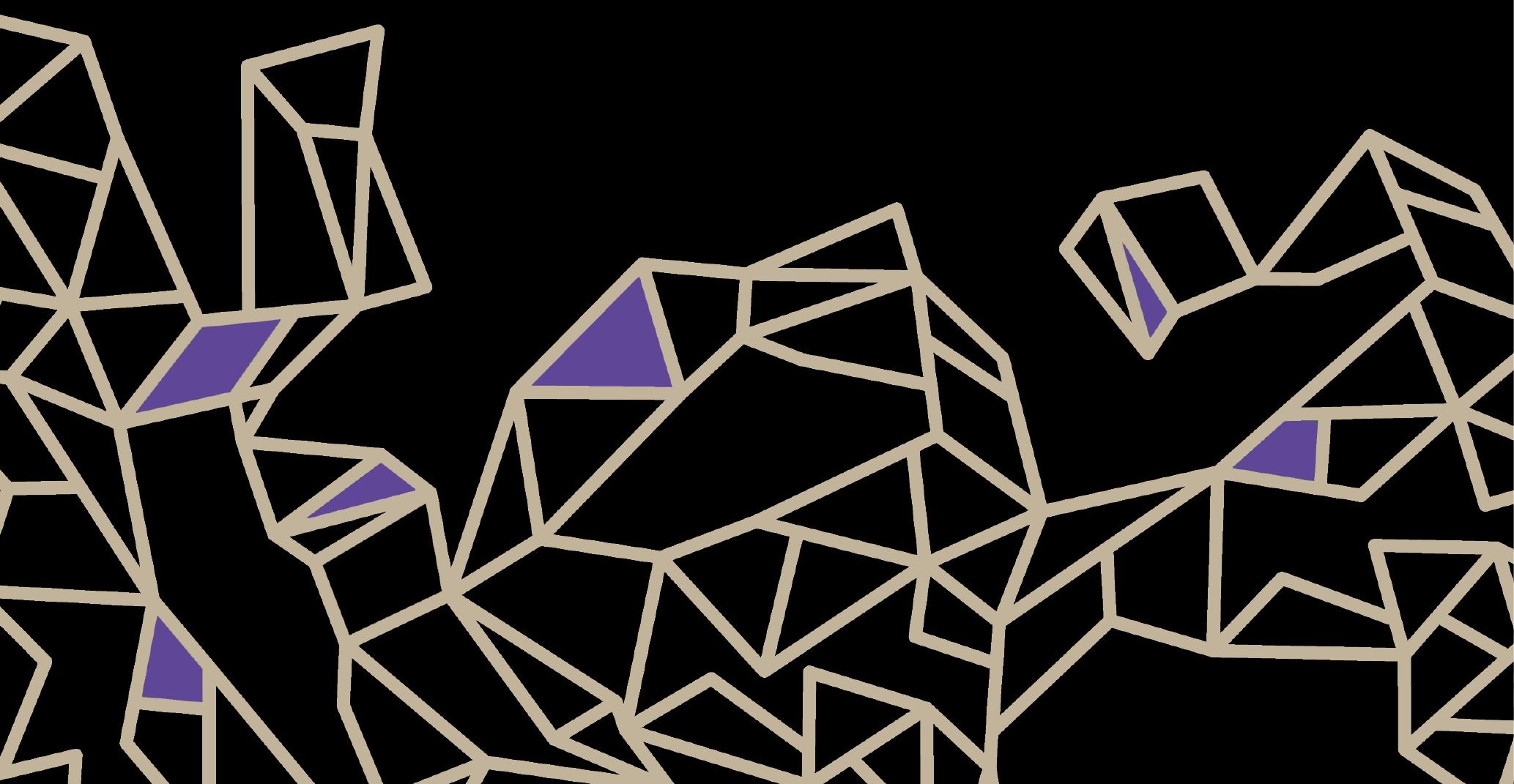




\section{Resumo}

Este artigo resgata os avanços de uma investigação que vem ocorrendo há anos sobre a teatralidade andina, e sobre o modo como esta se faz presente nas festas tradicionais do Peru, nas quais são manifestadas noções ancestrais em permanente estado de transformação. O caso específico dessa teatralidade aqui descrita e examinada é o da festa da Virgem de Carmem, em Paucartambo, Cusco, Peru. As fotografias que acompanham este artigo são da fotógrafa Pilar Pedraza e formam parte da mostra fotográfica "O Grande Teatro de Paucartambo".

Palavras-chave: Performatividade, Teatralidade "Paucartambo,' Peru.

\section{Abstract}

This article rescues the advances of an investigation that is occurring throughout the years on the Andean theatricality, and on how it is present in Peru's traditional festivals, in which ancestral notions in permanent transformation are manifested. The specific case of the theatricality described and examined here is the Virgem de Carmem festival, in Paucartambo, Cuzco, Peru. The photographs accompanying this article are from photographer Pilar Pedraza and are part of the photographic exhibition "The Great Theater of Paucartambo".

Keywords: Performativity, "Paucartambo" Theatricality, Peru.

\section{Buscando as origens}

O teatro europeu foi imposto na América desconhecendo as formas de representação que habitavam nessas terras, que, no melhor dos casos, foram classificadas com categorias ocidentais, sendo muitas delas proscritas com argumentos teológicos convergentes com as necessidades da conquista e da dominação. Durante a conquista e a colonização, com a exclusão dos indígenas - cuja condição de seres humanos, inclusive, foi posta em dúvida pela ideologia oficial - correspondeu a exclusão das práticas artísticas e culturais. Este último processo ainda perdura na atualidade. Na missão colonial aquilo que não podia ser erradicado foi incorporado como instrumento de interioriza- 
ção dos valores do catolicismo, utilizando para isso elementos de representação presentes na dança, na música e nas imagens, que posteriormente serão assimilados nas grandes realizações festivas. Assim, começavam níveis de mescla e sincretismo com os quais convivemos até hoje, e que constituem o encontro de elementos pré-hispânicos e cristãos em uma conjunção de ritos de distintas procedências. Perceber como opera este mecanismo sincrético é fundamental para entender a mescla e a "hibridação" dos processos culturais em constante movimento.

Durante o período colonial, muitas formas de representação pré-hispânica se moldaram de acordo com os parâmetros do teatro ocidental, ou seja, os "gêneros" autóctones encontrados pela conquista foram definidos tendo como referência um cânone espanhol, implicando os despojos das formas originais e extirpando delas a sua essência de evento efêmero, em alguns casos de rituais sagrados. Esta história é conhecida e merece ser lembrada, porque atualmente continuam desconhecidas as práticas cênicas que não correspondem à hegemonia cultural.

Os estudos sobre as origens do teatro peruano costumam ser realizados a partir de alguns textos escritos referidos ao teatro quéchua colonial. $O$ mais célebre deles é "Apu Ollantay", núcleo dramático pré-hispânico de origem quéchua que se conservou como tradição oral.

Também cabe mencionar como possíveis gêneros de origem pré-hispânico o "Wanka" e o "Aranway", definidos como "tragédia" e "comédia". Segundo a versão do cronista Jesús Lara, o "Wanka" se destinava à celebração das façanhas dos hierarcas, ao contrário do "Aranway", que representava a vida cotidiana. Aludir a esses gêneros como "tragédia" e "comédia" já é limitar as possibilidades de análise a categorias ocidentais para definir traços de performatividades originárias. Por outro lado, esse pressuposto reduz o teatro ao texto escrito e a um formato que certamente tem mais relação com um critério ocidental e evangelizador.

Cada época histórica, cada comunidade gera suas particularidades teatrais, suas formas de assumir o representacional, seus ritos, narrativas, personagens etc. Em consequência, ao buscar as teatralidades ancestrais, assim como sua continuidade no tempo supõem questionar alguns pressupostos generalizados e preestabelecidos como universais e inamovíveis no tempo. 
Os critérios que provêm do teatro ocidental privilegiam a narrativa linear e a hegemonia do texto escrito enquanto elementos determinantes.

Encontramos em práticas cênicas contemporâneas propostas orientadas a recuperar a essência do cênico como experiência viva, que tem princípio e fim, e que se sabem não existentes antes do momento efêmero de sua realização. $\mathrm{O}$ depois existe porque o espectador guarda em sua memória, passada a experiência vivida, em que o essencial é o jogo de relações e convenções que sustentam a convivência entre atores e espectadores. É esse o tecido de relações efêmeras que caracteriza o momento compartilhado. Essa convivência organizada ou espontânea pode ser realizada nos espaços mais distintos, onde há lugar para que as confluências de linguagens de diversas origens encontrem sua própria coerência. Dessa maneira, nos aproximamos inevitavelmente de princípios que estão presentes de modo coincidente em práticas representacionais de diversas culturas do mundo. Por tanto, o objetivo consiste em reconhecer outras teatralidades com quais convivemos e nas quais nos encontramos imersos, muitas delas mantidas em dinâmicas de jogo, que em muitas culturas foram consideradas a base do acontecimento teatral, partindo da designação de papéis, convenções e códigos de representação.

Importantes pensadores e realizadores teatrais do século XX, como Antonin Artaud, Jerzy Gorowski, Peter Brook e Eugenio Barba, entre outros, se perguntaram sobre o teatro sagrado, multicultural e antropológico, e tiveram evidências de formas de teatralidade presentes em rituais e celebrações teatrais em culturas originárias, propondo enfoques particulares em cada caso. Esses autores pensaram e ampliaram critérios para alcançar outros níveis de entendimento das práticas cênicas. Dirigiram um olhar atento para o sagrado, o ritual e o antropológico inquirindo em culturas autóctones da Ásia, África, América Latina e Caribe. Este olhar nos retorna como um espelho em cujo reflexo não nos confrontamos suficientemente com esse caudaloso imaginário cênico com o qual habitamos desde as origens de nossa civilização.

\section{Teatro e festa}

Para assistir à festa tradicional andina foi necessário considerar fontes de teatralidade presentes no comportamento e na representação de 
papéis do festivo-religioso, e na dramaturgia do espetáculo que opera. Especialmente, implicou examinar aquilo que se concentra no ator que dança, e que já pressupõe, nas palavras de Eugenio Barba, uma "situação de representação" devido à alteração do comportamento cotidiano e à elaboração simbólica que cristaliza. Essa mudança de enfoque implicou entender o teatro como totalidade integradora e não limitada à literatura dramática. Esse enfoque que engloba critérios integrantes e incorpora variadas performatividades, nas quais se confundem práticas sustentadas no corpo, na oralidade, nos ritos etc., nos parece mais adequado, sendo, sobretudo, um critério pertinente para avaliar as teatralidades em países de culturas ágrafas que até hoje mantêm elevados índices de analfabetismo.

Realizamos reflexões com o grupo Yuyachkani a partir da máscara, produzindo obras apoiadas nela, ou incorporando à cena presenças e/ou personagens provenientes da dança tradicional, especialmente andina. Essa prática tem sido marcada por buscas que já se estendem por 45 anos. Nosso trabalho implicou também a proposição de treinamentos físicos que têm como ponto de partida a aprendizagem de danças e o estudo do comportamento codificado inscrito no corpo do dançante, pretendendo com isso experimentar fisicamente aquilo que esse corpo manifesta.

Desde então, se falamos do teatro peruano, nos parece indispensável incorporar ao dançante mascarado, como um ator que dança no variado mosaico de teatralidades, esta outra escritura que se concentra no corpo e gera presença no espaço. Sem falar nos outros componentes que operam nos contextos da representação como são o uso do espaço, a maneira como se organiza a ação cênica, suas narrativas implícitas, composição, personagem, jogo, assim como as relações com os espectadores.

É dessa maneira que chegamos a Paucartambo, Cusco, no Peru, atraídos por uma fascinante festa em que o povoado é tomado pela multidão dançante mascarada, espectadores do lugar e outros que chegam de muitas partes para testemunharem o que acontece ali a cada ano: Diabos nos telhados, dançantes nos cemitérios, aproximadamente 20 grupos mascarados que não deixam de dançar nunca durante os três dias e noites que dura a festividade. Tudo em honra a Virgem de Carmem. 
Nessa festa ocorre uma organicidade cênica com cuja complexidade nós fomos nos familiarizando em sucessivas viagens, anos após anos, seguindo cada vez diferentes grupos de dançantes, escutando as pessoas e suas diferentes razões para estarem na festa, as diversas narrativas que as danças expõe, seus trajes e traços, e assim incorporando o que é contado sobre a chegada da Virgem ao povoado.

\section{Sobre os atores-dançantes}

A dança dos Q'apac Ch'unchu, os filhos queridos da Virgem e seus leais guardiões compartilharam comigo de maneira generosa sua memória. Em entrevistas e encontros sucessivos pude resgatar a história e as origens de sua dança, e por meio delas a interpretação que fazem do que ali sucede nesses dias de festa.

Não sou um observador imparcial. Os argumentos dos Ch'unchu foram decisivos para nortear meu olhar a respeito da versão que eles têm sobre a festa, como chegaram a Paucartambo e suas razões para permanecerem ao lado da Virgem para sempre.

Assim, este texto pretende fazer uma leitura da festa a partir das teatralidades que ali operam, dos comportamentos simbólicos dos dançantes mascarados, da memória retida no corpo dos atores que ali dançam, da construção de suas presenças/personagens, da situação de representação que operam as relações que estabelecem com os outros (espectadores, testemunhas, participantes), das narrativas de suas danças e de suas relações entre si, assim como dos diferentes usos do espaço que concretizam e seus modos específicos de performatividade.

Ainda que nosso olhar sobre as teatralidades paucartambinas leve em consideração os diferentes níveis que operam ali, se concentra especialmente no conflito que encarnam dois grupos de dançantes, os Q'hapac Q'olla e os Q'hapac Ch'unchu, ao redor dos quais se constrói o perfil ritual e mitológico do evento e que demarca, portanto, as tensões do fio condutor da festa. Eles são atores de um enfretamento que gira em torno da possessão da virgem. Ao mesmo tempo, esse conflito tem valores simbólicos que aparentemente aludem a combates de origem pré-hispânica: Ch'unchus e Q'ollas são perso- 
nagens que foram mencionados em registros do cronista da conquista espanhola Huamán Poma de Ayala.

Ch'unchus e Q'ollas são também protagonistas da grande narrativa desenvolvida durante três momentos-chave, nos três dias que dura a festa. Se nos restringíssemos a um padrão ocidental, diríamos que ali é apresentada uma obra de teatro em três atos (Q'onoy, Selva, Guerrilha) e que tem como cenário todo o povoado.

\section{Teatralidades no tempo}

Durante o período colonial, muitas formas de representação pré-hispânicas foram moldadas de acordo aos parâmetros do teatro ocidental. Os "gêneros" autóctones encontrados pelos conquistadores foram definidos, como já mencionado, a partir de um cânone cultural ocidental, e muitas daquelas práticas foram proscritas com argumentos teológicos, convergentes com as necessidades da conquista e da dominação.

Para chegarmos perto de distinguir performatividades originárias, vale tomar o termo quéchua "Taqui", que significa "dançar" e "cantar". Os Taquis nos remetem a um acontecimento representacional baseado no canto e na dança. Em outras palavras, "Taqui" aponta o sentido mais orgânico de se liberar o corpo e a voz para celebrar o plantio, a colheita, a caça de animais, os ritos de fecundidade, ou práticas coletivas vinculadas à terra, ao agradecimento às divindades e à despedida dos mortos. Essas duas atividades, ou expressões artísticas, a dança e o canto, estavam vinculadas uma à outra. Assim, sabe-se que não havia baile que não incluísse canto, ou cantos que não fossem acompanhados de danças, como ocorre até hoje.

Outro elemento que se deve observar quando se pensa em teatralidades originárias é a máscara. As máscaras são parte de um universo de personagens e danças, lugar mágico em que os mitos se encontram com a história, em que os homens conversam com os animais, em que os notáveis não morrem, e sim reencarnam nas montanhas e se convertem em Apus (espíritos sagrados) protetores de seu povo. É onde os personagens atravessam os tempos e se transformam, surgindo novamente seres metade homem e metade animal. Observam-se máscaras de papagaios, gaviões, cervos que 
conversam com os homens, máscaras do antigo kusillo (metade macaco metade homem), e dos Auquis, que representam o espírito das montanhas, ou em relatos em que os deuses falam com os animais e os homens.

Os contextos funerários também são fonte de informação da diversidade de usos das máscaras nas diversas culturas. Eles aludem a momentos vividos, combates de guerreiros, oferecimentos aos deuses, cerimônias rituais de poder etc., registrados em cerâmicas, telas, murais e templos, como é o caso do Chavín de Huantar.

Alguns casos sugerem uma continuidade surpreendente no tempo, como ocorre com as máscaras exibidas no museu Sicán de Ferreñafe (Chiclayo, Peru). Nelas pode ser vista a cabeça de um animal que pode ser uma raposa ou um morcego com a língua móvel. A estrutura dessa cabeça com a língua móvel compartilha traços similares aos das máscaras da dança dos diabos de Túcume e de Mochumi, da mesma região.

Desde o Peru pré-hispânico encontra-se um robusto calendário agrícola marcado por diferentes tipos de danças. É celebrado com danças o trabalho com a terra; o acompanhamento do gado; os nascimentos e as despedidas dos que se vão. A dança está presente na vida e na morte, e cada povoado dança para afirmar sua existência. Nesses contextos, a máscara é uma companheira inseparável da dança e afirma a vida coletiva.

A dança e tudo o que a acompanha em geral está inserida dentro da religiosidade popular. As festas de "santos" são onde aparecem por excelência os dançantes mascarados, seguramente cumprindo alguma promessa ao santo padroeiro. É a festa acompanhada obrigatoriamente de música, comida e bebida, danças e cerimônias o que une a comunidade.

Toda essa prática de representações também aparece nas festas tradicionais que ocorrem pelo país. Não deixa de ser surpreendente que nessas muitas celebrações da vida e da morte no Peru, que hoje permanecem vivas e se renovam, sempre está presente uma origem muito antiga.

Entre nós existe um vínculo atávico com a máscara que se mantém vivo e renovado. Esse vínculo pode ser encontrado em muitas festas e celebrações atuais, nas quais costumam aparecer traços ancestrais comuns, por exemplo, a maneira como os mortos são incorporados à festa, no dia em que o cemitério é aberto e os dançarinos chegam com suas alas para 
saudar os que já não estão presentes, como na festa da La Candelaria, em Puno, ou na própria festa da Virgem de Carmem, em Paucartambo, em Cusco, em que há um momento para ir ao campo santo para visitar os dançarinos que já morreram. Chegam as alas mascaradas com suas bandas, levando comida e bebida para continuar compartilhando a vida com os mortos. As máscaras são retiradas e colocadas sobre as tumbas, onde eles cantam, dançam, bebem e recordam os companheiros falecidos. Diante dessas tumbas ocorrem cerimônias de batismo ou de iniciação de novos dançantes, entre muitas outras práticas habituais neste compartilhamento com os mortos.

\section{O ator-dançante mascarado}

O mascaramento é o fator mais radical da representação porque supõe de início outra identidade que o dançarino deve assumir. Um dançarino mascarado me disse uma vez: "Eu sem a máscara sou incapaz de dançar qualquer coisa e muito menos de fazer o que faço. Mas quando coloco a máscara, já não me reconheço, sou capaz de fazer qualquer coisa". Isso é o que precisamente o uso da máscara pelo dançarino provoca e o que gera, em essência, um ato performativo que se inicia com a transformação do corpo mascarado. A máscara é a conexão atávica com o rito e com a memória que o dançarino cria e recria ao longo do tempo em seu dançar. Seu espaço orgânico são organizações coletivas, chamadas alas, que geralmente apresentam semelhanças no vestuário, acessórios, máscaras, e os respectivos momentos em suas danças em que confluem níveis de representação de diversas origens - canto, dança, música e jogo.

O dançante que porta máscaras de animais busca assumir suas qualidades e características. Em diversas cosmovisões, percebe-se a intenção de se integrar e formar parte do universo em equilíbrio e harmonia com o mundo natural, e em todas elas é encontrado o princípio comum do mascaramento e sua consequência evocativa de identidades diversas, de um corpo e identidade que se transforma e se recria. Esse recurso da representação está presente em todas as culturas do Peru. No dançante mascarado encontramos expressões de teatralidade contemporânea, incorporadas à festa e mescla- 
das com o rito e a representação. Ainda sob essas formas atuais aparecem signos ancestrais de jogo e representação.

\section{Entre presença e personagem}

Um personagem costuma ser definido por sua ação, pelo que faz e persegue e pelas estratégias que executa para alcançá-lo. Isso Ihe dá um propósito e uma linha que o conduz a uma peripécia que, finalmente, terá um desenlace. No entanto, a base que sustenta o vínculo diante do outro, o espectador, é dada pela simples presença, que gera curiosidade nessa relação espaço-temporal efêmera que tem começo e fim. Essa conexão também pode ser o início de um tecido complexo de relações que não têm necessariamente como objetivo primordial contar uma história baseada em narrativa explícita, com estrutura convencional de exposição - enredo e desenlace. Assim o espectador, estimulado pela imagem-ação, pode criar uma ou muitas histórias. Hoje isso é muito frequente no teatro contemporâneo, em que o narrativo não comparece como um objetivo, nem como um caminho unívoco. Muitas propostas teatrais modernas apontam como alternativa o espectador ser parte do processo criativo, como o faz a antiga festa da Virgem de Carmem de Paucartambo.

\section{Teatralidade e jogo}

O jogo aparece como um indicador importante na teatralidade andina, assim como é definido o teatro em outras culturas ("to play" em inglês, "jouer un rôle”, em francês, "eine Rolle spielen”, em alemão). Segundo Alfonsina Barrionuevo há um termo para defini-lo: Pukllay ("jogo"); Yachachikuy é "ensaiar"; Ilimp'kuy "maquilar-se"; pampakuy ou saynatakuy "mascarar-se". Pukllay (jogo) pode ser também um conceito que nos remete a diferentes maneiras de entender o cênico como o que acontece no Pukllayapampa (lugar de jogo) ao pé do apu Ausagante durante as festas em honra do senhor de Qoyllurity, em Cusco, em que os participantes desempenham papéis diferentes, por meio dos quais expressam seus desejos. É uma sofisticada forma de teatralidade, sustentada no jogo propriamente dito. É um 
contexto de oralidade em que aparecem personagens a partir da verbalização de papéis distintos. Durante esses jogos, são comprados e vendidos virtualmente: gado, terras cultiváveis, animais, veículos etc., simbolizados nos pagamentos e objetos oferecidos com pequenas pedras. Ainda assim são realizados casamentos, divórcios e recebidos títulos profissionais entre outras. Essa feira teatral dos desejos é um dos atrativos da festa, realizada em uma esplanada um pouco distante do templo na direção dos morros nevados. Ali vemos instalado um grande espaço preparado para o Pukllaypampa, termo quéchua que significa "pampa de jogo". Tratam-se de pequenos lotes feitos com pedras de diversos tamanhos, acomodadas umas sobre as outras, montículos que representam chácaras, casas, apartamentos pequenos ou grandes, com ou sem garagem etc. Tudo a gosto e de acordo com as possibilidades do interessado. Os vendedores anunciam as ofertas, os compradores se aproximam e pedem informação, que lhes é dada com detalhes de área, acabamento etc. As vendas são contabilizadas: uma chácara com animais pode custar entre cinquenta e sessenta mil dólares. Também circulam pelo lugar notários, testemunhos e padrinhos, oferecendo seus serviços para fazer a escritura dos respectivos contratos de compra e venda, e isso com toda a seriedade. Chama atenção a capacidade dos participantes de improvisar e sustentar o personagem. As pessoas jogam de verdade e acreditam, como no jogo de compra e venda de escrituras em que, uma vez realizada a escritura, buscam-se testemunhas entre os assistentes e faz-se a respectiva transição, depois da qual ocorre um rito de batismo da propriedade para o qual se deve comprar confetes, serpentinas e vinho, que se podem conseguir no lugar. No Pukllaypampa há um "banco" com guichê de atendimento, onde podem ser feitos depósitos de grandes somas de dinheiro compradas em sua entrada; cada depósito bancário vem acompanhado de seu respectivo voucher. Além de outras transações, tais como casamentos, divórcios e batismos; para isso não falta um "padre" para oficializar a cerimônia, nem um músico para acompanhar a celebração. Também são oferecidos títulos universitários das mais diversas profissões. Enfim, tudo é possível neste lugar de jogo: Pukllaypampa. Não me lembro de ver outro lugar onde uma multidão jogue o teatro com tanta veracidade. 


\section{Teatralidade paucartambina}

Participam da festa cerca de vinte grupos de dançarinos mascarados, cada um deles pertencente a distintos setores sociais do povoado, cujas respectivas danças contêm memórias e narrativas diferentes de acordo com a história e o segmento social a que pertencem. Uma população pacata ao longo de todo o ano altera seu cotidiano durante os três dias e as três noites que duram a festa. Nesse contexto de interação entre atores, habitantes e visitantes se produz uma convivência performática de grande força visual. Durante esses dias e noites, a vida cotidiana transcorre impactada pela presença e atividade de atores dançantes mascarados que percorrem o povoado em bandos, ou fora deles, caminhando, estabelecendo "relações" entre as pessoas e nos recordando que o teatro é um jogo de convenções e relações entre atores e espectadores. É essa relação efêmera que caracteriza o vínculo.

Nas ruas de Paucartambo, durante os dias da festa, os espectadores se veem confrontados com muitas presenças que geram intensos contatos visuais e mobilizam o imaginário. Durante os festejos, encontram-se sugestões de teatralidade originária, viva, em movimento, mesclada com signos do passado e do presente. Evento de grande dispêndio de teatralidade, a festa tem como protagonistas dois grupos de dançantes, cada um deles disputando a posse da imagem da Virgem. É na luta por esse objetivo que os Q'apac ch'unchu e os Q'apac qolla se enfrentam.

O vasto cenário que dá origem à festa inclui toda a geografia desse povoado de serra. $\mathrm{O}$ espectador assiste a um explosivo transbordamento de teatralidade viva e em movimento, em que são combinados signos procedentes do passado com outros mais recentes. $O$ conflito que as danças apresentam parece ter origem em um período anterior à conquista espanhola, e há signos que aludem a tempos mais remotos.

\section{Sobre os protagonistas}

\section{Dançantes Q'apac Ch'unchu}

Os Ch'unchus são procedentes da selva e chegaram a Paucartambo conduzidos pelo sonho de seu rei, Chontakiru, para se encontrarem com a 
Virgem de Carmem, depois de atacá-la para defenderem suas terras na selva e de oferecerem sua cabeça ao rio Amaru Mayu, que desde então passou a se chamar Madre de Dios. Por isso, quando os Ch'unchus chegam a Paucartambo e encontram a Virgem, decidem permanecer a seu lado para sempre e declaram-se seus fiéis guardiões. Sua razão de existir é protegê-la e garantir a permanência dela no povoado. Quando a Virgem sai em procissão, os Ch'unchus a vão cercando dos dois lados e o rei vai à frente. Sentem-se tão identificados com ela que se tornam parte da imagem da Virgem na procissão.

\section{Dançantes Q'apac Qolla}

Representam aos comerciantes que chegavam a Paucartambo vindo do planalto de Qollao. A dança chega encabeçada pelo prefeito, o Machu Qolla, sua mulher, a Imilla - representada por um homem com o rosto coberto por um pano negro - seu pequeno filho, qollita, e dois dançantes chamados capitães que vão ao lado do chefe. Seguem duas fileiras de dançantes chamados soldados, sempre acompanhados de uma Ihama viva, que forma com o grupo ao lado de um tratador encarregado de levá-la. Todos utilizam uma máscara de tecido chamada Waqollo, ressaltando em seu vestuário uma pele de carneiro dissecada pendurada na cintura. Os dançantes utilizam na cabeça adereços adornados com plantas coloridas, que formam desenhos e bordados variados. Essa dança remonta a uma lenda sobre uma mulher comerciante, nascida em Paucartambo, que em uma de suas viagens a Pucará (Puno) para vender seus produtos encontrou a cabeça da Virgem na casa onde se hospedou. Quando ela retornou a Paucartambo trouxe a cabeça, juntou ao resto do corpo da estátua e deu à igreja. Os Q'ollas interpretam cânticos tristes de conteúdo religioso, social e festivo. De fato, ao mesmo tempo que expressam tristeza são também personagens alegres, já que atuam de modo jocoso e condizente com o clima de festa. Essa dança representa as Ihamas, por isso, eles sempre se movem em grupo com um líder à frente, que escapa do conjunto e é chamado Salga Qolla (rebelde).

São esses dois grupos de dançantes que demarcam as tensões da festa, enquanto protagonistas de um enfrentamento de alto valor simbólico, que subjaz ao argumento conhecido pelo povo e se repete invariavelmente todos 
os anos como um rito teatral de afirmação de identidade. É em torno deles que se constrói o perfil ritual e mitológico do evento.

\section{Momentos-chave na representação da disputa pela virgem nas festividades paucartambinas}

\section{Q'onoy}

Para os dançantes de Q'hapac Ch'unchu, os Q'ollas iniciam seu desempenho em Paucartambo na véspera da festa (15 de julho). Durante o Q'onoy (noite do fogo) os Q'ollas acendem fogueiras e fogos artificiais; este é "o primeiro ataque" com o propósito estratégico de recuperar a Virgem. Segundo essa versão, os Q'ollas chegam a Paucartambo e por meio de uma ação desesperada incendiam o povoado como forma de intimidação que, estrategicamente, visa a levar com eles a Virgem cuja posse reclamam. Esse propósito explica a atrevida ação de "incendiar" o povoado, como uma demonstração de força e como um meio de aterrorizar os rivais. É por isso que os Q'hapac Ch'unchu, compreendendo a lógica dos inimigos, reagem rapidamente e assumem a defesa do povoado, logo repelindo o ataque. O rei, no comando de seu exército, enfrenta os adversários, garante a defesa do povoado e restaura a ordem, controlando a situação, apagando o fogo e fazendo retroceder os Q'ollas, que se veem frustrados no seu intento de levar com eles a Virgem de Carmem. No dia seguinte, os Q'ollas retornam com uma tática diferente, dessa vez tentando reconciliar-se com os habitantes do povoado.

\section{A selva}

Os Q'ollas armam um tablado bem alto no meio da praça e entre as palmeiras constroem uma selva artificial, que representa a selva de Qosñipata. Instalados na parte mais alta dessa cenografia efêmera, distribuem os produtos que trouxeram a Paucartambo na condição de comerciantes. Do tablado distribuem à multidão, que os espera, presentes que trouxeram: frutas, jarras de barro, colheres de madeira, cestas, bacias, lavatórios, pequenos bancos de madeira e múltiplos utensílios. Esses são ofertados a fim de promover a reconciliação com a cidade depois do Q'onoy (o incêndio que provocaram na noite anterior), e é esta ação enganosa que ocorre na selva. De fato, a entre- 
ga dos presentes esconde um objetivo militar. Os Q'apac Q'olla construíram esse tablado alto como parte de sua estratégia de combate. De lá poderão observar a localização e as posições ocupadas pelos Ch'unchus, e o "gesto amistoso" de oferecer presentes atinge o objetivo de neutralizar momentaneamente os habitantes. É uma tática de combate para desorientar e ganhar tempo até o dia seguinte, quando se realizará a guerrilha. Assim, finalizada a "selva", os Q'ollas consideram que já conhecem o inimigo de modo suficiente e se preparam para a ofensiva final.

\section{A guerrilha}

A "guerrilha" é o ponto culminante da festa. Encena um combate ritual que tem como cenário a praça principal do povoado. É um acontecimento de jogo coletivo, uma situação de representação em um espaço comum compartilhado por espectadores e dançantes em que se desenrola um argumento conhecido e com um final já esperado.

Depois de três dias seguidos de danças pelas ruas do povoado, as alas acompanham a Virgem até a velha ponte de pedra, que o rei Carlos III, no período colonial, ordenou que fosse construída para facilitar o trânsito dos habitantes e o pagamento dos tributos. Ali a Virgem abençoou os quatro Suyos (regiões geográficas nas quais se dividia o território no período incaico). Conta-se no povoado que "a Virgem não é daqui, veio só de visita. Por isso, no último dia, quando ela vai embora, ao chegar na metade da ponte, decide permanecer porque a trataram muito bem". Dali a "mãezinha" Carmem empreende o regresso a seu templo. Atravessa a praça e entra na igreja, enquanto os Saq'ras (diabos) a seguem observando pelos telhados com os rostos cobertos para não serem seduzidos por sua beleza. Os grupos dançantes se concentram na praça. O caos é percebido pela simultaneidade das danças e pelo som das bandas. Instaura-se uma desordem que contrasta com a calmaria dos dias anteriores: a Guerrilha está por começar.

Enquanto isso, os Q'ollas, como forasteiros que são, instalam-se em uma tenda colocada no centro da praça, que será seu quartel-general, de onde vão sair para provocar o povoado. Nele permanece muito bem protegida a Imilla, mulher do prefeito, chefe dos Q'ollas, com seus filhos. A Imilla é representada por um homem ágil que usa saia longa, xale e chapéu, mas 
sua principal característica é seu rosto coberto por uma máscara de pano negra, o que faz dela uma figura ambígua e extremamente enigmática, imagem associada à representação da Virgem de Carmem. Isso tem algum sentido metafórico que se faz evidente na guerrilha, já que um dos picos dramáticos do enredo se dá quando a Imilla é raptada pelos Ch'unchus.

Os espectadores paucartambinos conhecem bem a trama que vai ocorrer e assistem na condição de testemunhas, para jogar e esperar como será a representação daquele ano, porque o enredo não aceita modificações. As únicas mudanças se dão nas relações do jogo que são geradas a cada vez.

Antes do início da guerrilha vão aparecendo algumas danças que desenvolvem pequenas histórias que operam como ações prévias ao argumento central da guerrilha e funcionam como breves entremezes que são repetidos durante o trajeto circular da praça. É assim que aparecem os Maqtas (jovens), representando o trabalhador humilde do campo. Eles operam como bufões da festa e, ao mesmo tempo, têm a missão de impor a ordem, para que o público não invada a área de representação. Nos dias anteriores à festa, acompanharam a passagem da Virgem, quando foram pedindo aos fregueses que tirassem seus chapéus ou bonés em atitude de respeito à mãezinha Carmem. No início da guerrilha, vão aquecendo o ambiente proporcionando jogos relacionais com os espectadores. Esses cômicos andinos utilizam máscaras de nariz grande e amplo sorriso, estão soltos e não têm compromisso com nenhuma dança em particular, podendo servir-se de todas para exercitar o papel de jogar com os espectadores. Diferentemente de outros personagens mascarados, os Maqtas falam e o fazem com uma voz aguda de falsete, que é o registro de voz dos mascarados andinos não só nesta, mas também em outras festas. Os Maqtas sempre apresentam surpresas e podem ter consigo animais dissecados, câmeras fotográficas que espirram água, telefones celulares de brinquedo, vísceras de animais etc. Sua maneira de se relacionar tem quase sempre uma conotação sexual, mas também pode fazer referência de maneira irônica à situação política do momento, comentar notícias atuais com imagens ou abraçar alguma mulher desprevenida e forçá-la a acompanhá-los, dando voltas ao redor da praça até deixá-las exaustas. Isso funciona como uma antecipação paródica do que será, mais adiante, o conflito principal da guerrilha: o rapto da Imilla pelos 
Ch'unchus. O que parece estar atrás desse jogo é a intenção de comentar o que está em disputa naquela tarde: a possessão e guarda da Virgem. Os Maqtas não deixam de interagir com os espectadores, o que garante que o evento tenha todo o tempo a condição de um jogo.

Os Chuqchos ou Palúdicos apresentam outra dança que ocorre antes da guerrilha, e fazem sua aparição com feridas visíveis na face de suas máscaras amareladas. Representam os trabalhadores que regressam da selva infectados pela malária, sendo uma sátira da medicina ocidental. Convulsionam, desmaiam e são atendidos por enfermeiros bufos, que Ihes aplicam injeções gigantes e serrotes, realizando cirurgias. Uma caveira mascarada com tesoura na mão é integrada à ala. Alguns levam ramas, denotando a região de onde vêm, e outros levam saquinhos cheios de farinha para jogar nos espectadores. Também forma parte da dança o patrón que leva uma rama larga na mão e tem ataques de febre terçã, um personagem com asas que representa o bicho que propaga o mal.

A dança dos doutorzinhos ou siqllas, também presentes nesse momento prévio à guerrilha, representa uma sátira aos tinterillos (subalternos que trabalham nos tribunais), juízes, advogados de ambos os sexos, personalidades do poder judicial, sempre aludidos de forma crítica e burlesca, a partir das formas de administração da justiça. Eles seguem coerentemente vestidos de negro, os homens vestindo toga e cartola e as mulheres saia social, colete, luvas e bengala. Os Siqllas percorrem o espaço realizando pequenas cenas cômicas com uma forte crítica social parodiando os magistrados do poder judicial. Carregam ainda um imenso livro chamado "caracho" com o título "O peso da lei". Em sua caminhada realizam julgamentos sumários de um personagem que acompanha as alas e representa um camponês pobre, que recebe ao fim do rápido julgamento a sentença inevitável, é golpeado com "O peso da lei" ou em outras vezes recebe chicotadas nas costas. Os doutorzinhos seguem seu caminho e vão ensinando aos curiosos por meio de livros menores que são abertos e fechados rapidamente e deixam entrever imagens de revistas pornográficas, contrastantes com seu comportamento senhorial, de passos alargados e lentos, com a coluna vertebral ereta e a cabeça ligeiramente inclinada para trás. Alguns doutorzinhos são acompanhados de empregados que carregam suas malas. Seus passos lentos e atitude 
contemplativa denotam a segurança de quem se sente com a razão que é dada pelo exercício do poder.

As alas da Waca-Waca, dança que satiriza a festa de touros espanhola no ritmo do pasodoble, percorre as ruas do povoado levando um touro amarrado pela cabeça como se fosse realizar a "corrida." Eles realizam alguns lances como laçadas, passeio da quadrilha, jogo com o capote etc. No dia da "guerrilha," os Waca-Waca concentram-se no perímetro da praça. Nesta dança os personagens são: o touro, representado por um dançarino com roupa brilhosa branca, usando uma máscara de malha de fios negros, dois toureiros; um laçador; dois Maqtas que tocam o touro; a cholita (carinhosamente chamada a mulher andina); a dona do touro etc. A passagem da ala taurina termina quando o touro é submetido, morto e exibido em procissão ao redor da praça no compasso da marcha fúnebre de Morán (a mesma música será escutada novamente no final da guerrilha, quando passarão carregando o vencido e morto chefe dos Q'ollas pela praça do povoado). A morte do touro marcará, efetivamente, o início da guerrilha.

Lembro-me que na primeira vez em que estive na festa, e tentando interpretar o que estava acontecendo, perguntei a um habitante do povoado que estava perto de mim: "o que é que está acontecendo?" Ele me respondeu: "Eles estão se divertindo". Essa resposta simples me levou a um aspecto da teatralidade que costumamos esquecer: o jogo, princípio fundamental da trama de convenções e relações que o fato cênico gera.

O espaço onde se realiza a representação da guerrilha é circular. Toma-se toda a praça, criando-se um grande corredor entre o perímetro e o centro. Grupos de espectadores ocupam o centro da praça como se fosse uma ilha e instalam-se na margem dela para olhar. Carregam bancos e cadeiras criando assim vários níveis para observação como em uma arquibancada, até a calçada das ruas em volta é tomada pelos espectadores que se acomodam bem cedo, da mesma forma como acontece nas bancadas das câmaras municipais, nos anfiteatros das escolas, médicas etc. O espaço circular da praça onde ocorre a ação supõe que os atores-dançarinos repitam suas ações muitas vezes enquanto dão voltas ao redor do espaço. Assim, os atores jogam com o argumento, caminham ou correm o tempo todo realizando infindáveis sequências que se sucedem e repetem diante dos espectadores e com a 
participação deles, já que estes compartilham um espaço comum com os atores-dançarinos.

O particular uso de espaço e o fato de não pararem, porque estão sempre em ação, prendem a atenção dos espectadores, propondo um ritmo que não decai, sobretudo pela magistral administração do tempo que os atores-dançantes fazem. Considerando que o argumento da trama é conhecido pelos assistentes, o que particulariza as representações, a cada ano, é o desenvolvimento e ritmo das ações e o jogo de relações entre atores e espectadores.

Para começar a guerrilha os Q'ollas bloqueiam os três acessos à praça. Colocam uma manta com a qual farão uma oferenda à "Mãe Terra", e por meio das folhas de coca mascadas poderão ler o futuro e assim saber se a guerriIha Ihes será ou não favorável, ainda que todos saibamos que, como sempre, eles serão os perdedores.

Todo esse momento preambular, no desenvolvimento do enredo propriamente dito, caracteriza-se pelo jogo de relacionamentos dos espectadores e dançantes.

Ao mesmo tempo, os Q'ollas fazem arder em panelas de barro uma mescla de palha com sementes de pimenta seca. Em seguida, amarram suas huaracas (espécie de estilingue) às asas das panelas para carregá-las e apontar a ardência seca no rosto dos espectadores, que têm de se movimentar para que o vapor não Ihes alcance os olhos. Esta queimada dos Q'ollas pode ser compreendida como uma purificação do ar, para protegerem-se dos males que chegam das selvas, lugar de onde vêm seus inimigos, os Ch'unchus. Esse momento também pode ser entendido como provocação aos próprios habitantes do povoado. Não se esqueça de que segundo a versão dos Ch'unchus, os Q'ollas chegam a Paucartambo com a intenção de recuperar a Virgem, portanto, tomam a iniciativa nos combates. Esse tipo de provocação se intensificará porque, mais adiante, atacarão com suas huaracas carregadas de projéteis. Desse modo, laranjas, entre outras coisas serão atiradas nos espectadores, especialmente aqueles que se encontram sentados nas bancadas. A "agressão" continua quando percorrem o espaço agitando garrafas de cerveja para jogar as espumas nos espectadores.

Esse jogo de personagens e de danças é simultâneo e mesclado em toda a praça. Os Q'ollas cuidam da Imilla e seu rapto pelo rei dos Ch'unchus 
é o que desata o nó da trama principal. Os Q'ollas saem para enfrentar os Ch'unchus e recuperar a Imilla sequestrada, mas vão sendo paulatinamente derrotados. Trazem espelhos e pequenas cruzes para "assustar os selvagens" A cada vez que um Q'olla é atingido os Ch'unchus Ihe colocam duas canas na frente como se formassem uma cruz, simbolizando assim sua morte: os Ch'unchus têm na ponta de suas lanças uma fruta envenenada que espremem na cara de seus inimigos, para que não se levantem mais e assegurarem-se de que os venceram. No entanto, alguns Q'ollas conseguem escapar e se escondem entre o público, ou pedem um último desejo aos seus captores, como o de fazer chamadas com telefones de brinquedo e pedir reforços. O registro desses personagens durante a "guerrilha" é farsesco, e este é um elemento-chave no plano da teatralidade com qual se opera a representação do conflito, pois é também expressão da dualidade andina que nos apresenta personagens opostos e complementares.

Os Q'ollas lutam em tom de burla, enquanto os Ch'unchus brigam sem tréguas, com firmeza e dignidade. Essa diferença de registros torna muito mais interessante o conflito dramático, porque os personagens antagônicos não o são somente por terem objetivos opostos, mas também pelas suas diferentes maneiras de jogar enquanto personagens. Imaginemos o que aconteceria se o enfrentamento ocorresse entre personagens que estão em um mesmo registro. A "comédia" costuma ter um personagem sério e outro burlesco, sendo essa oposição que gera a comicidade pelo contraste. Por outro lado, em uma guerra costuma-se ter mortos, e o fato de que os Q'ollas estão de alguma maneira jogando com a morte permite que se a veja como algo próximo, natural, com a qual se convive e que inclusive integra a festa, como quando há uma visita ao cemitério feita com seriedade. Durante a "guerrilha", como foi mencionado, a morte também aparece integrada ao espaço lúdico da festa. É curioso ver as distintas maneiras como morrem os personagens, já que nenhum morre igual ao outro.

Os Saqras ou diabos, que dias antes tínhamos visto pelos telhados das casas escondendo-se da Virgem para não serem seduzidos por sua beleza, participam atentos, dando voltas com seu carro de fogo decomposto, uma plataforma com quatro rodas incendiadas na qual se acomodam os Q'ollas mortos para retirá-los do campo de batalha e quem sabe levá-los ao inferno. 
Os Q'ollas desempenham seu comportamento cênico de maneira farsesca, e até no momento de morrer não deixam de fazer brincadeiras. Por outra parte, os Ch'unchus lutam sem perder a compostura. Esse dispositivo de tensões é muito comum nas diferentes tradições teatrais, tanto asiáticas como ocidentais. Para citar um exemplo, no teatro Balinês, que também exibe um exuberante universo de máscaras, há um personagem que expressa seu conflito brincando com seu oponente.

O desenlace da guerrilha começa quando o chefe dos Q'ollas cai abatido: é nesse momento que os Ch'unchus cruzam suas lanças à maneira de uma maca e colocam o cadáver sobre ela, passeando depois ao redor da praça em consideração a sua alta patente. O corpo do chefe Q'olla jaz sobre as lanças com a cabeça dependurada. O cortejo avança. É difícil ver o corpo porque os imensos chapéus de plumas dos Ch'unchus cobrem a visão quase completamente.

Atrás do cortejo desfilam dignamente o rei Ch'unchu com a Imilla. Os soldados Q'olla avançam chorando dissimuladamente, cobrindo a cabeça com as mantas; o tom grotesco de seu canto Ihes dá uma aura ambígua de vencidos/não vencidos. Sua atitude não é a de um derrotado que aceita plenamente sua derrota. Ela sugere uma revanche. Nós, espectadores presentes, sabemos que regressarão no próximo ano e tentarão de novo. A "guerrilha" terminou.

Dessa forma, a festa chega ao fim e as bandas musicais entoam marchas fúnebres. Os Ch'unchus dançam em volta do inimigo vencido. Uma procissão desfila encabeçada pelo Rei dos Ch'unchus, que vai acompanhado da imagem e de seu séquito. Logo começa o Cachapari, ou fim da festa, com todas as bandas ao redor da praça tocando simultaneamente.

Cada comunidade inventa sua própria teatralidade, suas maneiras de assumir a dimensão representacional e os significados dos personagens, as histórias que contam e muitos outros elementos que fazem parte desse universo. Se o teatro é uma construção cultural, Paucartambo gera a sua contemporaneamente.

Recebido em 19/04/2016 Aprovado em 16/05/2016 Publicado em 01/07/2006 